UDC $535.3 ; 535.37 ; 538.975$

DOI: $10.17308 / \mathrm{kcmf} .2019 .21 / 1147$

Received 27.06.2019

Accepted 15.08.2019

\title{
APPLICATION OF LUMINESCENCE AND ABSORPTION SPECTRA TO CONTROL THE FORMATION OF A HETEROJUNCTION IN NANOSTRUCTURED RUTILE FILMS SENSITIZED BY CdS QUANTUM DOTS
}

\author{
(c) 2019 S. B. Kuchev ${ }^{1}$, A. N. Latyshev ${ }^{2}$, L. Yu. Leonova², O. V. Ovchinnikov², E. V. Popova ${ }^{2}$ \\ ${ }^{1}$ Voronezh State Technical University \\ 14, Moskovskii pr., 394026 Voronezh, Russian Federation \\ ${ }^{2}$ Voronezh State University \\ 1, Universitetskaya pl., 394018 Voronezh, Russian Federation
}

\begin{abstract}
The effect of photon processing (FO) on the formation of a heterojunction in the $\mathrm{TiO}_{2} / \mathrm{QD}$ 'sCdS interface obtained by applying separately synthesized CdS quantum dots to the $\mathrm{TiO}_{2}$ film in the rutile phase has been studied. The changes of luminescence spectra and absorption of the investigated samples after this treatment discovered. It is shown that the separation of charge carriers occurs only after irradiation of samples with a powerful light pulse of a xenon lamp.
\end{abstract}

Keywords: quantum dots, luminescence and absorption spectroscopy, cadmium sulfide, titanium dioxide, heterojunction.

\section{INTRODUCTION}

Wideband gap semiconductors are used in photocatalysis, solar energy converters and optoelectronics. In the last decade, sensitization by other semiconductors with a smaller band gap has been used to expand the scope of application and increase the efficiency of these devices [1]. In particular, titanium dioxide having a band gap in the rutile phase $3.05 \mathrm{eV}$ is widely used as a wideband semiconductor. And to sensitize it in the visible region of the spectrum, chalcogenides of some metals, for example $\mathrm{CdS}$, are used. In this case, the boundary between $\mathrm{TiO}_{2}$ and $\mathrm{CdS}$ there is a heterojunction of type II according to Andersen [2]. The bottom of the cadmium sulfide conduction band is located above the bottom of the titanium dioxide conduction band. This means that when the CdS is excited by light quanta, the photoelectrons pass into $\mathrm{TiO}_{2}$, the holes remain in the CdS. This is the process of separation of the photoexcited electron-hole pair, which leads to the efficient operation of devices with such heterojunction. A similar situation occurs if the sensitizer is used in the form of quantum dots (QDs) [3-5].

Crystal lattices $\mathrm{TiO}_{2}$ and $\mathrm{CdS}$ very much differs, that leads to impossibility of creation ideal hetero-

Popova Elena Vyacheslavovna, e-mail: elina.vacheslavovna@gmail.com junction between them [6, 7]. Consequently, the interface between them can contain various point defects, which will be an obstacle to the separation of charge carriers. This creates the need to search for treatment ways of a $\mathrm{TiO}_{2} / \mathrm{QDCdS}$ heterostructure to improve the interface and control the process of separation of charge. There is a method of treatment by powerful light pulses in which the rearrangement of the crystal structure of a substance is very effective [8]. This efficiency is caused by the appearance of giant vibration amplitudes of a limited number of modes corresponding to some effective temperature, much higher than the equilibrium temperature. We used this photon processing (PP) method to treat the $\mathrm{TiO}_{2} / \mathrm{QDCdS}$ heterostructure in order to improve the properties of the interface. The control was carried out using luminescence and absorption spectra.

\section{MATERIALS AND METHODS}

\subsection{Investigated samples}

Samples of $\mathrm{TiO}_{2} / \mathrm{QDCdS}$ were synthesized by the following way. At first nanocrystalline films of titanium dioxide were obtained. For this a thin titanium film was formed on the surface of the fluoroflogopite substrate by electron-beam evaporation and condensation [9]. Then it was oxidized on 
air in a resistance heating furnace at temperatures of $673-1273 \mathrm{~K}$ during 60 minutes. This technique provided the formation of $\mathrm{TiO}_{2}$ layers with a thickness of $0.8 \mu \mathrm{m}$. The synthesis of colloidal QD CdS was carried out under the conditions of the dropby-pouring out of aqueous solutions of $\mathrm{CdBr}_{2}$ and $\mathrm{Na}_{2} \mathrm{~S}$ into an aqueous solution of alkaline inert photographic gelatin with constant stirring of the reaction mixture at a temperature of $313 \mathrm{~K}$ [10]. Synthesis was carried out at $\mathrm{pH}=7$. The growth of QDs was stopped by the termination of a chemical process due to the cessation of the supply of precursor solutions to the reaction area. QDs CdS was released from gelatin by treatment in the solution of Pancreatin. To limit the aggregation of QDs ultrasonic treatment of the resulting suspension was used. The resulting aqueous suspension of QDs CdS was deposited onto a titanium dioxide film. At the same time, measures were taken to ensure that the number of quantum dots did not exceed the value required for the monolayer. The samples were dried at a temperature of $300 \mathrm{~K}$ and placed in a chamber in which they were subjected to photon treatment by the radiation of high-power pulsed xenon lamps for 2 seconds. During the exposure time at the location of the sample, the radiation energy incident on an area of one square centimeter was $230 \mathrm{~J}$.

\subsection{METHODS OF INVESTIGATION AND EQUIPMENT}

Rutile films were studied using fast electron diffraction and transmission electron microscopy (TEM) on EMB-100BR and Tecnai G2 20F S-T (FEI) microscopes. The studies of QDs CdS were carried out on a Libra CarlZeiss 120 electron microscope and a Thermo ARLX'TRA X-ray diffractometer. The $\mathrm{TiO}_{2} /$ QDCdS heterostructure was studied on a LEO $912 \mathrm{AB}$ Omega transmission electron microscope.
The transmission spectra of the samples in the visible and near UV regions were measured on a spectrophotometer USB2000+(OceanOptics, USA). The luminescence spectra in the spectral range 400-860 nm were measured on an automatic spectral-luminescent complex consisting of an MDR-23 diffraction monochromator (LOMO, Russia), to the output slit of which the photomultiplier R928P was connected. The photomultiplier worked in photon counting rŭgime. The power source was C4900-51 (Hamamatsu, Japan). Operation was carried out by a computer through the interface unit.

\section{RESULTS AND DISCUSSION}

\subsection{Morphological characteristics}

The TEM image of $\mathrm{TiO}_{2} / \mathrm{QDCdS}$ samples (Fig. 1a) shows a block substructure with block sizes up to $100 \mathrm{~nm}$. The grain size of which the blocks are made is about $20 \mathrm{~nm}$. All reflections of the electron diffraction pattern correspond to rutile (Fig. $1 b$ ). The spectrum of the characteristic X-ray radiation of investigated samples (Fig. 1c) indicates the presence of a small number of $\mathrm{Cd}$ and $\mathrm{S}$ atoms in addition to titanium and oxygen atoms. Peaks corresponding to copper are an artifact due to the subject grid. The relative intensities of the peaks indicate that the content of $\mathrm{Cd}$ and $\mathrm{S}$ in the samples does not exceed $1.0 \%$. The data on the spectral properties of the synthesized samples given below confirm the presence of the CdS phase on the surface of rutile films. In figure $2 a$ shows the TEM image of colloidal QDs CdS. Their size distribution is relatively wide, with maximum in the $3.25 \mathrm{~nm}$ region (Fig. $2 c$ ). Moreover, after their release from gelatin, the average size increases and becomes equal to $3.75 \mathrm{~nm}$ (Fig. $2 d$ ). In fig. $2 b$ shows an X-ray diffraction pattern of these QDs, from which it follows that their structure corresponds to the cubic CdS crystal lattice.
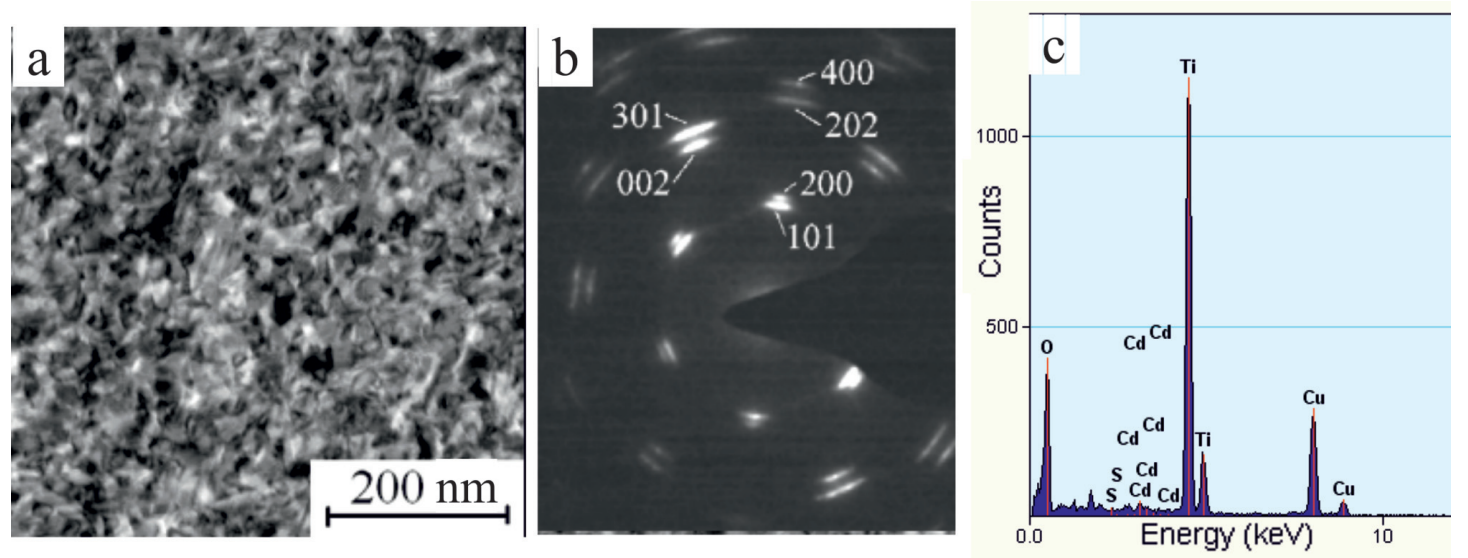

Fig. 1. TEM image (a), microelectron diffraction pattern $(b)$ and the energy spectrum of the characteristic $\mathrm{x}$-ray radiation of the $\mathrm{TiO}_{2} / \mathrm{CTCdS}$ heterostructure $(c)$ 

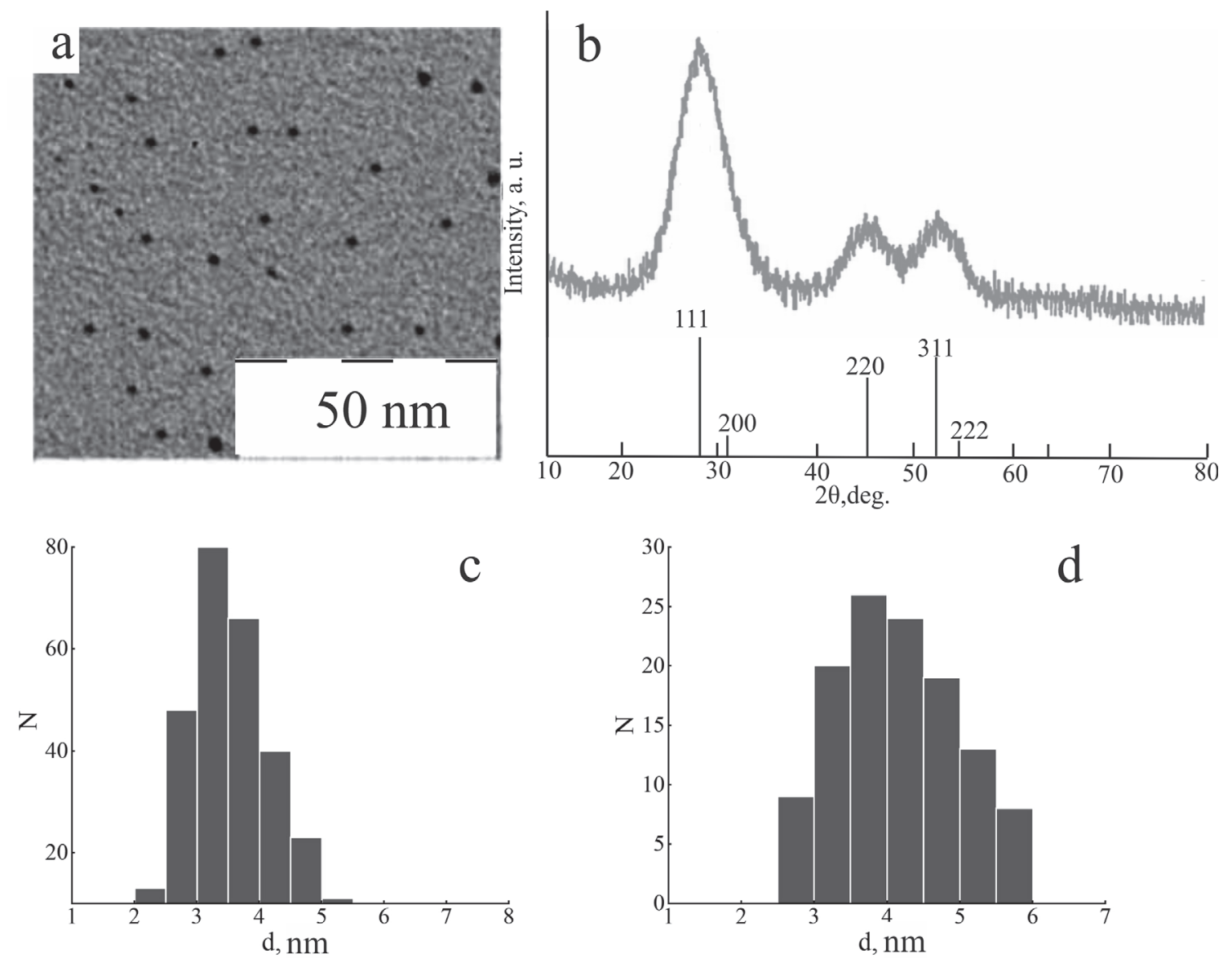

Fig. 2. Electronic photography $(a), \mathrm{x}$ - ray diffractogram $(b)$, size distribution of colloidal QDs CdS in gelatin $(c)$ and size distribution of QDs CdS released from gelatin $(d)$

\subsection{Optical characteristics}

The absorption spectrum of a $\mathrm{TiO}_{2}$ film is shown in Fig. 3, curve 1. The edge of the absorption band is located near $400 \mathrm{~nm}(\sim 3.1 \mathrm{eV})$. It well corresponds to literary data for rutile [1]. Curves 2 and 3 of this figure are the absorption spectra of samples of a $\mathrm{TiO}_{2}$ film with QDs CdS deposited on it before and after the PP, respectively. It is clearly seen that they extend to $500 \mathrm{~nm}$, where rutile practically does not absorb. This result agrees well with the data of [11].The curves have maximum values at $420 \mathrm{~nm}$ (curve 2) and $440 \mathrm{~nm}$ (curve 3). Absorption of cadmium sulfide begins in this part of the spectrum [5, 12]. The observed maxima correspond to the first allowed transition of QDs CdS [13].

Luminescence of the samples was excited by radiation from a wavelength of $365 \mathrm{~nm}$ (photon energy $3.4 \mathrm{eV}$ ). In this case, the energy of quantum is near the edge of the titanium dioxide absorption band. In the luminescence spectra of all samples there is a band at $850 \mathrm{~nm}$ (Fig. 3, curves 4-6), what is consistent with the work [9]. This band is the most intense for $\mathrm{TiO}_{2}$ film (curve 4). Its maximum decreases approximately ten times after depositing the emulsion QDs CdS to the film (curve 5). The PP leads to a significant restoration of intensity, which reaches a more than $40 \%$ of the magnitude at the maximum before this treatment (curve 6).

The application of a film of the emulsion containing QDs, leads to another very important result. A band with a maximum near $720 \mathrm{~nm}$ (curve 5) appears which corresponds to the quantum dots of cadmium sulfide $[14,15]$. But the most interesting is the fact of the complete disappearance of this band after the PP (curve 6).

Thus, the absorption and luminescence spectra make it possible to control the presence of a relatively small number of CdS quantum dots deposited on thin rutile film, as well as to reveal the effect of the PP procedure on the optical properties of the $\mathrm{TiO}_{2} /$ QDCdS samples under study.

\subsection{Discussion of obtained results}

Using the obtained results, we consider the physical processes that occur in the samples under study before and after the PP procedure. First of all, it should be noted that the absorption of untreated 


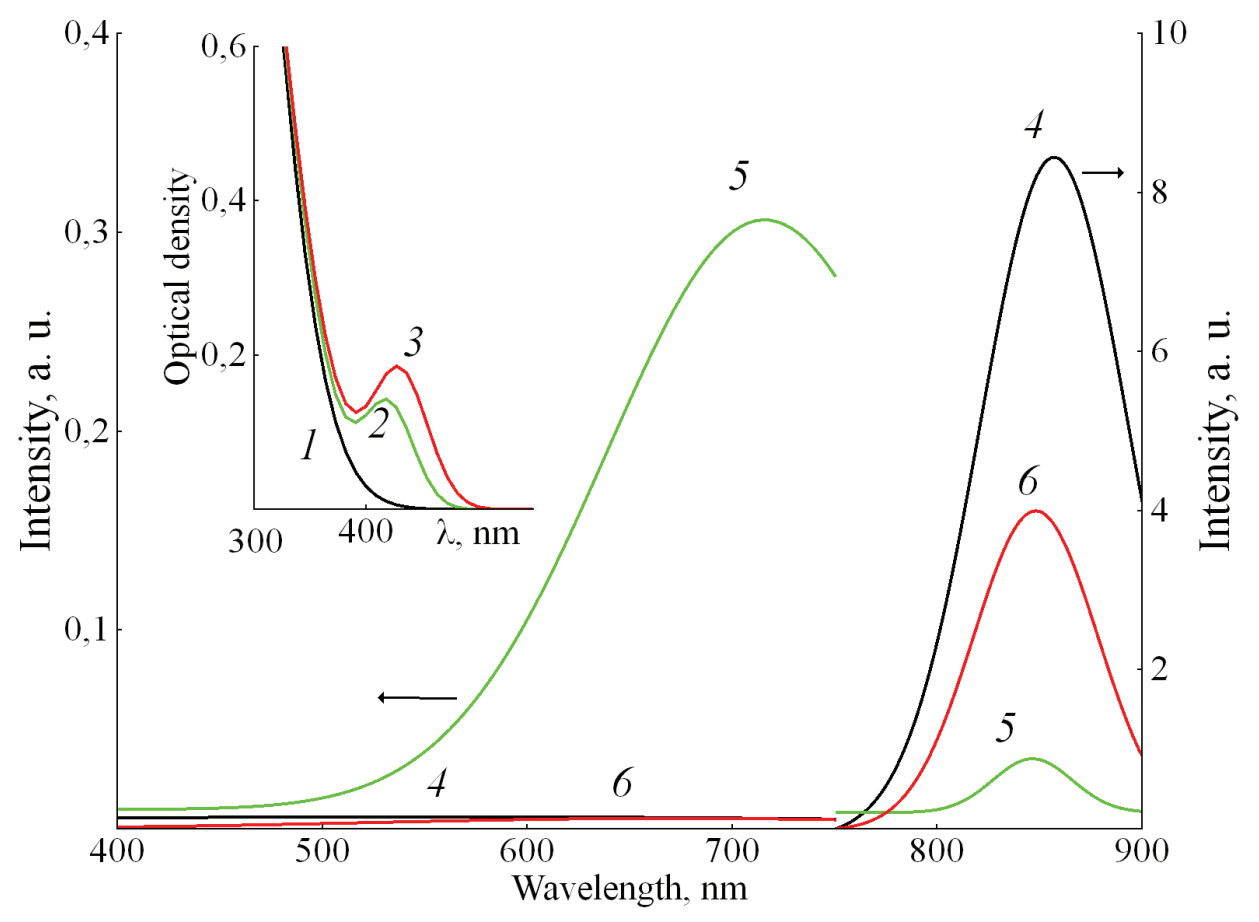

Fig. 3. Luminescence spectra at $77 \mathrm{~K}$ of $\mathrm{TiO}_{2}$ film (curve 4) and $\mathrm{TiO}_{2} / \mathrm{QDCdS}$ heterostructure before (curve 5) and after the PP (curve 6). The luminescence was excited by radiation with a wavelength of $365 \mathrm{~nm}$. Inset: absorption spectra of $\mathrm{TiO}_{2}$ film (curve 1) and QDs CdS before (curve 2), and after the PP (curve 3)

and treated of the PP samples $\mathrm{TiO}_{2} / \mathrm{QDCdS}$ in the range of 400-500 $\mathrm{nm}$, where titanium dioxide in the rutile phase does not absorb, indicates the presence of cadmium sulfide in them. The optical density of these samples at a wavelength of $365 \mathrm{~nm}$ is $0.23-$ 0.24 (Fig.3, curves 2 and 3, respectively). The optical density at this wavelength of the $\mathrm{TiO}_{2}$ film is 0.11 (Fig. 3, curve 1). The difference between these values is $0.14-0.15$. This value is the optical density of the cadmium sulfide layer deposited on the film in the form of QDs CdS. It will be used in further discussions on the intensity of the luminescence bands. In addition, the obtained value makes it possible to estimate the effective thickness of the QDs CdS layer. Indeed, the absorption coefficient of cadmium sulfide in the near ultraviolet range reaches $1.5 \cdot 10^{5} \mathrm{~cm}^{-1}[16]$. Therefore, the thickness $9-10 \mathrm{~nm}$. This value is approximately $1.25 \%$ of the film thickness, which is in order of magnitude in good agreement with the above data on the concentration of $\mathrm{Cd}$ and S elements obtained by $\mathrm{x}$-ray atomic analysis. It should be borne in mind that the contribution of light scattering by quantum dots was not taken into account in this estimate. Therefore, the resulting thickness of the QDs layer is too high.

As noted above, the presence of maxima on curves 2 and 3 (Fig. 3 ) is a sign that cadmium sul- fide after depositing the suspension QDs CdS on the film is stored in the form of quantum dots before and after the PP. Their position relative to each other (420 and $440 \mathrm{~nm}$ ) indicates that the size of QDs CdS increases slightly after FO. Indeed, the shift of the absorption edge by $20 \mathrm{~nm}$ to the longwave side of the spectrum corresponds to an increase in the size of the nanoparticles by only $0.1 \mathrm{~nm}$ [13]. Therefore, if the size of the QDs that were deposited on the $\mathrm{TiO}_{2}$ film had an average size of $3.75 \mathrm{~nm}$ prior to the PP, then after the PP their average size should be equal to $3.85 \mathrm{~nm}$. The increase in the average size of QDs as a result of the PP occurs, apparently, due to the destruction of the smallest particles. Curve 3 is above the curve 2 . We assume that this is due to the increase in light scattering in the samples under study as a result of the PP. For the final conclusions, this fact is not of great importance.

Now we turn to the rest of the curves of Fig. 3, which are luminescence spectra. The decrease in the intensity of the band at $850 \mathrm{~nm}$ by a factor of ten after depositing the aqueous suspension QDs CdS (Fig. 3, curve 5) can occur for two reasons. The first reason is the partial absorption of the exciting radiation by the QDs CdS layer. Indeed, if the optical density of the QDs layer located on the $\mathrm{TiO}_{2}$ film in the region of $365 \mathrm{~nm}$ is approximately equal 
to $0.14-0.15$, the intensity of the exciting radiation reaching the film will be $70 \%$ of the value in the absence of the CdS layer. The second reason is presumably the enhancement of nonradiative transitions that occur due to moisture residuals after drying of the film. After the PP procedure, the intensity of this band is partially restored (curve 6). Its intensity at the maximum increases approximately four times, reaching a little more than $40 \%$ of the maximum value before the PP. This result cannot be explained only by the absorption of exciting radiation by QDs CdS layer. It would be assumed that the channel of nonradiative transitions after the PP continues to exist, although it is significantly weakened. However, the experiment showed that the band at $720 \mathrm{~nm}$ after PP completely disappears, which contradicts the partial weakening of the channel of nonradiative transitions. This contradiction cannot be explained by the evaporation of QDs under the influence of the PP, since the maxima corresponding to the first optical transitions of QDs CdS are present in the absorption spectra (Fig. 3, curves 2 and 3). But it is easy to explain by the fact that after the PP heterojunction in the interface between microcrystals of $\mathrm{TiO}_{2}$ film and QDs CdS occurs. In this case, the electrons excited in the QDs CdS must pass to the titanium dioxide film, leading to the disappearance of the $720 \mathrm{~nm}$ band.

The result is that the intensity of the luminescence band at a maximum of $850 \mathrm{~nm}$ after the FA (Fig. 3, curve 6) does not reach $70 \%$ of the initial value (curve 4 ). This can also be explained by the emergence of heterojunction. Indeed, when the microcrystals of the $\mathrm{TiO}_{2}$ film are excited by radiation, part of the holes localized on the centers of luminescence, which are intrinsic lattice defects $[14,15]$. Another part of the free holes can go to QDs CdS due to the charge separation process in the presence of heterojunction. If their number is about $30 \%$ of the total, the intensity of the maximum luminescence of the titanium dioxide film with QDs CdS at $850 \mathrm{~nm}$ should be $40 \%$ of its intensity without QDs. Since the intensity of the band maximum at $850 \mathrm{~nm}$ after the $P P$ is exactly this value, and the band at $720 \mathrm{~nm}$ disappears, it is quite likely that the heterojunction is established as a result of this procedure.

\section{CONCLUSION}

As a result of the experiment and discussion of its results, the following conclusions can be drawn.

1. Complex studies of samples of $\mathrm{TiO}_{2} / \mathrm{QDCdS}$ using electron microscopy, x-ray atomic analysis, luminescence and absorption spectroscopy were given the opportunity to establish that the photon processing forms a heterojunction in the interface between the QDs and microcrystals of $\mathrm{TiO}_{2}$ films.

2 . It is possible to reliably establish the fact of the separation of charge carriers occurs at the heterojunction by measuring the luminescence spectra of the samples $\mathrm{TiO}_{2} / \mathrm{QDCdS}$.

3. The application of an aqueous suspension of QDs CdS on $\mathrm{TiO}_{2}$ film and subsequent drying of the samples does not lead to the formation of a heterojunction. In this case, QDs CdS have good luminescence, and the intensity of the $\mathrm{TiO}_{2}$ luminescence band decreases sharply due to nonradiative transitions.

4. Photon processing of the studied samples within a few seconds significantly restores the intensity of the $\mathrm{TiO}_{2}$ band. The luminescence of QDs CdS is completely quenched.

5. The titanium dioxide films obtained by heat treatment in air a previously deposited layer of titanium at a temperature of $673-1273 \mathrm{~K}$ are formed in the phase of rutile and have a block structure with block sizes up to $100 \mathrm{~nm}$. The blocks consist of grains, the size of which reaches $20 \mathrm{~nm}$.

\section{ACKNOWLEDGEMENTS}

The authors express their gratitude to academician V. M. Ievlev for participation in the discussion of the results and valuable comments.

\section{CONFLICT OF INTEREST}

The authors declare the absence of obvious and potential conflicts of interest related to the publication of this article.

\section{REFERENCES}

1. Kapilashrami M., Zhang Y., Liu Y.-S., Hagfeldt A., Guo J. Probing the Optical Property and Electronic Structure of $\mathrm{TiO}_{2}$ Nanomaterials for Renewable Energy Applications. Chem. Rev., 2014, v. 114, pp. 9662-9707. DOI: $10.1021 / \mathrm{cr} 5000893$

2. Dang T. C., Pham D. L., Le H. C., Pham V. H. $\mathrm{TiO}_{2} / \mathrm{CdS}$ nanocomposite films: fabrication, characterization, electronic and optical properties. Adv. Nat. Sci. Nanosci. Nanotechnol., 2010, v. 1, p. 015002. DOI: 10.1088/2043-6254/1/1/015002

3. Qian X., Qin D., Bai Y., Li T., Tang X., Wang E., Dong S., Photosensitization of $\mathrm{TiO}_{2}$ nanoparticulate thin film electrodes by CdS nanoparticles. J. Solid State Electrochem., 2001, v. 5, pp. 562-567. DOI: 10.1007/ s100080000179

4. Baker D. R., Kamat P. V. Photosensitization of $\mathrm{TiO}_{2}$ nanostructures with CdS quantum dots: Particulate versus tubular support architectures. Adv. Funct. Mater., 2009, v. 19, pp. 805-811. DOI: 10.1002/ adfm. 200801173 
5. Cheng S., Fu W., Yang H., Zhang L., Ma J., Zhao H., Sun M., Yang L. Photoelectrochemical performance of multiple semiconductors (CdS/CdSe/ZnS) cosensitized $\mathrm{TiO}_{2}$ photoelectrodes. J. Phys. Chem. C, 2012, v. 116, pp. 2615-2621. DOI: 10.1021/jp209258r

6. Khlyap H. Physics and technology of semiconductor thin film-based active elements and devices. Bentham Science Publisher, 2012. DOI: 10.2174/978160805021 51090101

7. Milnes A. G., Feucht D. L. Hetero junctions and metal-semiconductor junctions. Academic Press, $418 \mathrm{p}$. DOI: 10.1016/B978-0-12-498050-1.X5001-6

8. Ievlev V. M., Latyshev A. N., Kovneristyi Y. K., Turaeva T. L., Vavilova V. V., Ovchinnikov O. V., Selivanov V. N., Serbin O. V. Mechanism of the photonic activation of solid-phase processes. High Energy Chem., 2005, v. 39, pp. 397-402. DOI: 10.1007/s10733-0050078-2

9. Ievlev V. M., Kushchev S. B., Latyshev A. N., Ovchinnikov O. V., Leonova L. Y, Solntsev K. A., Soldatenko S. A., Smirnov M. S., Sinelnikov A. A., Vozgorkov A. M., Ivikova M. A. Relation of absorption band edge of rutile films and their structure. Inorg. Mater. Appl. Res., 2014, v. 5, pp. 14-21. DOI: 10.1134/ s2075113314010055

10. Korolev N. V., Smirnov M. S., Ovchinnikov O. V, Shatskikh T.S. Energy structure and absorption spectra of colloidal CdS nanocrystals in gelatin matrix. Phys. $E$ Low-Dimensional Syst. Nanostructures, 2015, v. 68, pp. 159-163. DOI:10.1016/j.physe.2014.10.042.
11. Ghazzal M. N., Wojcieszak R., Raj G., Gaigneaux E.M. Study of mesoporous cds-quantumdot-sensitized $\mathrm{TiO}_{2}$ films by using $\mathrm{x}$-ray photoelectron spectroscopy and afm. Beilstein J. Nanotechnol, 2014, v. 5, pp. 68-76. DOI: 10.3762/bjnano.5.6

12. Ahire R. R., Sagade A. A., Deshpande N. G., Chavhan S. D., Sharma R., Singh F. Engineering of nanocrystalline cadmium sulfide thin films by using swift heavy ions. J. Phys. D. Appl. Phys., 2007, v. 40, pp. 4850-4854. DOI: 10.1088/0022-3727/40/16/014

13. Ekimov A., Onushchenko A.A. Size quantization of the electron energy spectrum in a microscopic semiconductor crystal. JETP Lett., 1984, v. 40, pp. 1136-1139.

14. Rolo A. G., Stepikhova M. V., Filonovich S. A., Ricolleau C., Vasilevskiy M. I., Gomes M. J. M. Microstructure and photoluminescence of CdS-doped silica films grown by RF magnetron sputtering. Phys. Status Solidi Basic Res., 2002, v. 232, pp. 44-49. DOI: 10.1002/1521-3951(200207)232:1<44::AID PSSB44>3.0.CO;2-4

15. Smyntyna V., Skobeeva V., Malushin N. The nature of emission centers in CdS nanocrystals, $R a$ diat. Meas., 2007, v. 42, pp. 693-696. DOI: 10.1016/j. radmeas.2007.01.068

16. Ehemba A. K., Socé M. M., Domingo J. J., Cisse S., Dieng M. Optimization of the properties of the back surface field of a $\mathrm{Cu}$ (In, Ga) $\mathrm{Se}_{2}$ thin film solar cell. American Journal of Energy Research, 2017, v. 5(2), pp. 57-62. DOI: 10.12691/ajer-5-2-5

УДК 535,3; 535,37; 538,975

DOI: $10.17308 / \mathrm{kcmf} .2019 .21 / 1147$

Поступила в редакцию 27.06.2019

Подписана в печать 15.08.2019

\title{
ПРИМЕНЕНИЕ СПЕКТРОВ ЛЮМИНЕСЦЕНЦИИ И ПОГЛОЩЕНИЯ ДЛЯ КОНТРОЛЯ ОБРАЗОВАНИЯ ГЕТЕРОПЕРЕХОДА В НАНОСТРУКТУРИРОВАННЫХ ПЛЕНКАХ РУТИЛА, СЕНСИБИЛИЗИРОВАННЫХ КВАНТОВЫМИ ТОЧКАМИ CdS
}

\author{
(2019 С. Б. Кущев ${ }^{1}$, А. Н. Латышев ${ }^{2}$, Л. Ю. Леонова ${ }^{2}$, О. В. Овчинников ${ }^{2}$, Е. В. Попова ${ }^{2 \bowtie}$ \\ ${ }^{1}$ Воронежский государственный технический университет \\ Московский пр., 14, 394026 Воронеж, Российская Федерация \\ ${ }^{2}$ Воронежский государственный университет \\ Университетская пл., 1, 394018 Воронеж, Российская Федерация
}

\begin{abstract}
Аннотация. В этой статье сообщается о результатах влияния фотонной обработки (ФО) на формирование гетероперехода на границе раздела $\mathrm{TiO}_{2} / \mathrm{KTCdS}$, полученным путем применения отдельно синтезированных квантовых точек $\mathrm{CdS}$ к пленке $\mathrm{TiO}_{2}$ в фазе рутила.
\end{abstract}

$\triangle$ Попова Елена Вячеславовна, e-mail: elina.vacheslavovna@gmail.com 


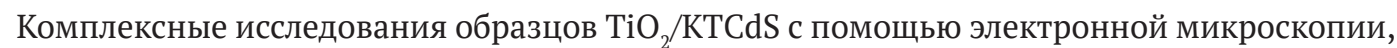
рентгеновского атомного анализа, люминесцентной и абсорбционной спектроскопии позволили установить, что при фотонной обработке образуется гетеропереход на границе раздела КТ и микрокристаллов пленок $\mathrm{TiO}_{2}$. Это исследование является значительным, поскольку потенциал таких многокомпонентных пленок используется в фотокатализе, преобразователях солнечной энергии и оптоэлектронике.

Ключевые слова: квантовые точки, люминесцентная и абсорбционная спектроскопия, сульфид кадмия, диоксид титана, гетеропереход.

Кущев Сергей Борисович - д. ф.-М. н., профессор, Воронежский государственный технический университет, Воронеж, Российская Федерация; e-mail: kushev_sb@mail.ru. ORCID: 00000003-1263-1806.

Латышев Анатолий Николаевич - д. ф.-м. н., профессор, кафедра оптики и спектроскопии, Воронежский государственный университет, Воронеж, Российская Федерация; e-mail: latyshev@phys.vsu.ru. ORCID: 0000-0002-72710795.

Леонова Лиана Юрьевна - к. ф.-м. н., Воронежский государственный университет, Воронеж, Российская Федерация; e-mail: liana. leonova@mail.ru. ORCID: 0000-0003-4171-4176.

Овчинников Олег Владимирович - д. ф.-м. н., профессор, зав. кафедрой оптики и спектроскопии, Воронежский государственный университет, Воронеж, Российская Федерация; e-mail: Ovchinnikov_O_V@rambler.ru. ORCID: 0000-00016032-9295.

Попова Елена Вячеславовна - инженер, Воронежский государственный университет, Воронеж, Российская Федерация; e-mail: elina. vacheslavovna@gmail.com. ORCID: 0000-00027565-2535.
Kuschev Sergei B. - Dr. Sci. (Phys.-Math), Full Professor, Voronezh State Technical University, Voronezh, Russian Federation; e-mail: kushev sb@mail.ru. ORCID: 0000-0003-1263-1806.

Latyshev Anatoly N. - Dr. Sci. (Phys.-Math), Full Professor, Department of Optics and Spectroscopy, Voronezh State University, Voronezh, Russian Federation; e-mail: latyshev@phys.vsu.ru. ORCID: 0000-0002-7271-0795.

Leonova Liana Yu. - Cand. Sci. (Phys.-Math), Voronezh State University, Voronezh, Russian Federation; e-mail: liana.leonova@mail.ru. ORCID:00000003-4171-4176.

Ovchinnikov Oleg V. - Dr. Sci. (Phys. - Math.), Professor, Head of the Department of Optics and Spectroscopy, Voronezh State University, Voronezh, Russian Federation; e-mail: Ovchinnikov_O_V@rambler.ru. ORCID: 0000-0001-6032-9295.

Popova Elena V. - Engineer, Voronezh State University, Voronezh, Russian Federation; e-mail: elina.vacheslavovna@gmail.com.ORCID:0000-00027565-2535. 